\title{
19
}

\section{Early childhood education policy pathways: A learning story}

\author{
Sandy Farquhar and Andrew Gibbons ${ }^{1}$
}

\section{Introduction}

Aotearoa New Zealand's twenty-first-century policy directions for early childhood education and care were set out in Pathways to the Future (MoE 2002). Pathways is regarded as a significant policy development within New Zealand and internationally (Wells 2015; May 2017). Developed by a centre-left, Labour-led coalition government, it ushered in a period of radical, far-reaching, progressive changes within the early childhood education sector. While not fully achieving its goals within its targeted 10-year period, it was and still is a reference point for the long-term governance of early childhood education (ECE). In 2002, the government's restructuring of the economy posed major challenges to social policy development in New Zealand, including that for ECE. Despite the reforms, Pathways looked like a runaway success until it was curtailed following the election of the National Government in 2008. Political commentator Colin James suggested it was 'arguably Labour's most important initiative, its biggest idea' (cited in May 2015). This big idea - a comprehensive vision and framework for the sector-was internationally recognised as an innovation in education policy.

1 The authors report no known conflict of interest. 
As a policy innovation, Pathways recognised and promoted ECE as being worthy of significant investment and development. It articulated a vision of all children participating in ECE and identified the strategies required to develop and maintain high-quality education. Providing a coherent, farreaching direction for a fast-growing sector, Pathways offered a blueprint for funding and regulation and served as a mechanism for supporting community-based ECE development. It suggested stronger government engagement with ECE provision and promoting teacher qualifications and professionalisation as hallmarks of quality. It set out three goals- to 'increase participation in quality ECE services', improve the quality of ECE services and 'promote collaborative relationships' - the last of which includes strategies for the 'building of an ECE sector responsive to the needs of Māori and Pasifika peoples' (MoE 2002: 3).

Strategies for implementing Pathways were summarised by the Ministry of Education (MoE 2002) as involving a complex mix of approaches: funding, regulation, information and support. Effectively, Pathways laid the foundation for a raft of changes to support the development of ECE. In terms of education spending, funding rates increased for all teacher-led services, equity funding grants were introduced, study grants provided incentives for staff to increase their qualifications and extra funding was available for teachers' professional development. Pathways included a revision of ECE regulations and a review of the early childhood curriculum, Te Whäriki (MoE 1996), particularly its support for curriculum development in early childhood care and education centres. In terms of informing and supporting the sector, the Ministry of Education established a collaborative research initiative called Centres of Innovation, showcasing exemplars of inquiry into curriculum practices in ECE. The ministry followed this plan, rationalising, regulating, integrating and supporting ECE providers and developing a series of ongoing evaluations of policy developments. Throughout this period, rapid change occurred in the sector, including a move towards increasing the qualifications of teachers (an anticipated 100 per cent qualified by 2012) and registration of all early childhood teachers. These shifts were accompanied by the introduction of pay parity with schoolteachers for kindergarten teachers and the development of professional standards for kindergarten teachers (MoE 2004). Curriculum delivery was supported with the development of the assessment guidelines, Kei Tua o te Pae: Assessment for learning-Early childhood exemplars (MoE 2005, 2007, 2009a) and the implementation of teacher self-review guidelines (MoE 2006). To support increased participation, '20 Hours Free ECE' was introduced (for further analysis, see Farquhar and Gibbons 2010; Gibbons and Farquhar 2014). 


\section{Successful pathways}

The success of Pathways as government policy is most evident in its innovative management of the diverse and complex issues that influence ECE. A successful ECE policy program and process in Aotearoa New Zealand has to navigate significant political tensions and challenges, both philosophically and pragmatically. These tensions and challenges include resistance to shifts from normalised childrearing traditions towards institutionalised care and education; disagreement over the relationships between care and education for children before school associated with a history of confusion as to where the sector's portfolio should lie; and the ongoing emergence of sometimes contradictory research evidence regarding child development, pedagogy and outcomes. As a noncompulsory sector, ECE has many different provider organisations. There is competition between for-profit ECE providers and not-for-profit community services, which introduces tension to the sector. Broader challenges for ECE policy development include political agendas that contemplate the use of the sector as leverage for social, political and economic goals, at both the national and the global levels.

Pathways was (and continues to be, to some extent) successful because it acknowledged these political issues and regarded inclusive and robust debate as vital to its strategic vision. In this sense, Pathways had broad social and political appeal. It responded to well-documented statistics and research on the needs of the labour market, on the changing dynamics of (mainly dual-income) families and on the benefits of ECE as a social good. It mobilised a series of networks and programs to keep policy attuned to the changing social and political climate, embracing the strength of the whole sector as critical to success, rather than targeting and isolating the sector's various elements.

Historically, the contest for provision of ECE has been fraught at a number of levels that broadly reflect differing social and political values around the role of women and children and differing philosophies about how rights are conferred on particular groups in society. Conservative and neoliberal governments in Aotearoa have construed education as a private good accruing to individuals, as a form of self-investment. Social-democratic governments in Aotearoa tend to recognise ECE as a public good, although they continue to support private investment and have stopped short of free 
universal provision. Hence, Pathways has successfully walked a political tightrope, steadfastly promoting its core goals for more than a decade and maintaining general acceptance across the political spectrum.

Esteemed internationally as one of the first strategic plans for ECE, Pathways has been celebrated by leading scholars and international organisations for its role in the development of an integrated and bicultural approach to both curriculum and policy. Peter Moss (2007, cited in May 2015: 147) argues that New Zealand's early childhood policy direction has led the way in confronting 'wicked issues', providing 'integrated approaches to funding, regulation, curriculum and qualifications'. The OECD's Starting Strong II report (2006) also lauds New Zealand for its commitment to an integrated system of funding and regulation. Despite recent backsliding by government and a generally unfavourable political climate, Pathways has maintained social and political currency within the sector, with its central tenets of quality, participation and collaboration supported by an active global policy push and a localised demand for affordable quality care to respond to the expectations of working families.

Pathways has been the most far-reaching early childhood policy strategy in Aotearoa in recent times and is clearly a policy success for a number of reasons. It had structural implications for the entire sector, addressing the needs of families, government and society. It featured inclusive consultation and collaboration and has been kept alive by recognised and credible leaders within the sector. It did the hard social and political work needed for later policy initiatives to flourish. Its implementation mechanisms provided evidence of ongoing success and, furthermore, it has sustained engagement with key stakeholders over a long period. Its effectiveness lay in the power of its policies and its emphasis on collaboration within the sector, providing optimal conditions for a thriving ECE sector and for future policy development. Mintrom and Norman (2009: 649) suggest that 'small teams can do much to draw attention to policy problems, present innovative policy solutions, build coalitions of supporters, and secure legislative action'. Pathways is an ideal example of such movement; it is an innovative policy solution that has garnered strong sectoral, social and political support. As Wells argues, its success stems from its focus on children and families, its deliberateness and its collaborative process:

Ngā Huaraki Arataki [Pathways to the Future] was not a random event or simply a good idea at the time. It was evidence based, and built on the experiences and knowledge of the sector. It sat within a world view that what happens for our youngest citizens matters. It was at a time 
when significant research around brain development was emerging, children's first years being critical in shaping their future. The focus was unequivocally on children and their families and whānau [family]. (Wells 2015: 7)

Pathways provided a cohesive platform for diverse curriculum and policy developments to support a dynamic and rapidly evolving sector, focusing strongly on building social cohesion through the promotion of collaborative relationships. The advocacy and scholarship of a number of key individuals played a vital role in policy development, providing a strong thread of continuity of care and stewardship.

The GFC in 2008, along with the election of a right-leaning government, signalled strong headwinds for a number of the plan's goals, although the program and its intentions continued to be valued and supported by many in the sector. At the time of writing (2018), a newly elected, leftleaning coalition government had reinvigorated many of the unrealised intentions of Pathways, announcing a consultative process for developing a new strategic plan for early childhood.

\section{Social, political and institutional contexts and challenges}

This section addresses the social and political contexts in which Pathways developed, sets out the challenges faced by the stewards of this policy in achieving its aims and traces the complex dynamics that influenced its development. Pathways emerged as part of a 'third way' approach to social policy in the early 2000s. It had its roots in the early advocacy work of women in the 1970s and 1980s, in wider public concerns about social justice and Māori empowerment (concerns acknowledged in establishing the Ministry for Women and the Department of Māori Affairs) and in a growing interest in child development research (May 2017). Pathways was, then, a clear and successful manifestation of three decades of advocacy by many key individuals and groups around the country. From the mid1980 s, a radical-right restructuring of political, economic and social policy moved Aotearoa from a liberal welfare state to a neoliberal state. Thus, Pathways is embedded in a number of narratives about economic rationalism, labour markets and gender over a period of intense economic and political change. While these narratives have shifted over the years 
in response to a range of social, economic and political directions, what remains constant is the need for ECE policy to gain social acceptance and political traction.

The first part of this section briefly sets out the early policy advocacy work of the 1980s and 1990s that was designed to secure government support for education and care as a way to improve the lives of children and women. It then explores the impact of a period of neoliberal reforms from 1984 to 1999 focused on economic productivity and efficiency as part of the global economy, which had harmful and long-lasting effects on individual and social wellbeing at the local level. The prevailing narrative focused on labour market needs, the expansion of care for children in institutions outside the home and an increasingly economic thrust of ECE policy under the influence of international institutions such as the OECD. This is the context from which Pathways emerged in the early 2000s. The third part of this section addresses a set of goals, broadly established some years earlier (Meade 1988) and developed in the plan as a response to what may be seen as an ongoing failure of the New Zealand Government's social policy. The goals addressed three perceived concerns: young children's lack of participation in ECE—particularly Māori and Pasifika children; inconsistent quality of provision and implementation of the curriculum; and the deleterious effects of marketisation on communities. Table 19.1 outlines key policy and curriculum developments since 1980 .

Table 19.1 Key policy and curriculum developments, 1980-2018

\begin{tabular}{|l|l|}
\hline $\begin{array}{l}\text { State Services Commission's Report on Early Childhood Care } \\
\text { and Education }\end{array}$ & 1980 \\
\hline Education to be More & 1988 \\
\hline Before Five & 1988 \\
\hline $\begin{array}{l}\text { Te Whāriki: He Whāriki Mātauranga mō ngā Mokopuna o } \\
\text { Aotearoa-Early childhood curriculum }\end{array}$ & 1996 \\
\hline $\begin{array}{l}\text { Pathways to the Future: Ngā Huarahi Arataki-A ten-year plan } \\
\text { for early childhood education }\end{array}$ & 2002 \\
\hline $\begin{array}{l}\text { Kei Tua o te Pae: Assessment for learning-Early childhood } \\
\text { exemplars }\end{array}$ & $2005,2007,2009$ \\
\hline $\begin{array}{l}\text { Ngā Arohaehae Whai Hua: Self-review guidelines for early } \\
\text { childhood education }\end{array}$ & 2006 \\
\hline $\begin{array}{l}\text { Te Whatu Pōkeka: Kaupapa Māori assessment for learning-Early } \\
\text { childhood exemplars }\end{array}$ & 2009 \\
\hline An Agenda for Amazing Children: Final report of the ECE Taskforce & 2011 \\
\hline Te Whāriki: Early childhood curriculum. & 2017 \\
\hline
\end{tabular}


Prior to 1980, as a legacy of more than 140 years of British colonisation, the normalised model of ECE involved families (that is, mothers) raising their children at home (Ritchie and Ritchie 1970). The New Zealand Free Kindergarten Association provided free, public, sessional education for three- and four-year-olds, although the morning or afternoon sessions did not generally release a parent or caregiver to seek employment. Longday childcare arrangements were marginally acceptable in exceptional circumstances, such as when normal family life had broken down. Aside from kindergartens, ECE was largely unregulated, fragmented, staffed by an unqualified workforce and, for the most part, ignored by politicians and the general public (see Ritchie and Ritchie 1970).

Throughout the 1980s, various reports emerged in response to a growing demand for child care-for example, the State Services Commission's Report on Early Childhood Care and Education (1980). The Early Childhood Workers Union and the New Zealand Childcare Association voiced concerns about poverty, the plight of women and children and workers' conditions in early childhood centres. When the Labour Party came to power in 1984, it was the first time its policy manifesto mentioned early childhood services-in particular, 'the support of child care with an affirmative action for women' (May 1990: 102). With progressive and supportive intentions, the government made small steps towards developing policy for ECE, shifting the responsibility for all early childhood services to the Department of Education and introducing funding provisions, training initiatives and support services. Although many in early childhood saw these as steps in the right direction, they were limited and none of the promised support was felt by parents in terms of affordability and access or by childcare workers, who still received 'the lowest wages in New Zealand' (May 1990: 102).

Despite minimal shifts in both policy and associated conditions for early childhood services, the Labour Government was generally seen as empathetic - a background against which a working group led by Anne Meade was established to identify key issues and directions for the nation's youngest learners and its diverse education sector. The resulting report, Education to be More (Meade 1988; generally referred to as the Meade Report), was followed soon after by the Government policy Before Five (Department of Education 1988). These two documents marked the recognition of ECE as a legitimate and important sector in education. The Meade Report set out a blueprint for the organisation and structuring of the entire sector, including a level of funding that, if delivered, would 
have supported all early childhood services. The Meade Report and Before Five ensured a strong foothold for ECE within education, recommending a comprehensive system of funding and an organisational framework for the entire sector predicated on equity for women and children and a belief in state provision. The scene was set for the later development and implementation of the curriculum, Te Whäriki (MoE 1996)-the world's first fully recognised national and bicultural curriculum dedicated to ECE.

However, the intentions of the Meade Report were never fully realised. The report was stymied by reforms within the wider education sector, which was inextricably caught up in neoliberal political and economic discourses, which championed decentralisation, deregulation and devolution of services that had traditionally been provided by the state (Kelsey 1995; May 2017). Changes ensued across all areas of social policy, including education and ECE. This neoliberal turn undermined some of what was intended in the first iteration of Before Five. Hastily rewritten to ensure acceptance by Treasury, Before Five still managed to provide a strong policy platform for ECE, despite many of its intentions being effectively thwarted by budget cuts and legislation that promoted a decentralised and entrepreneurial culture. When prime minister David Lange introduced Before Five, he told early childhood representatives that gaining funding was like 'snatching raw meat out of the jaws of a Rottweiler' (Mitchell 1994: 97). The New Zealand Business Roundtable and other key proponents of the New Right's economic discourse were spelling out the political and economic advantages of decreasing government expenditure. The Treasury wrote a paper for the Cabinet, advising minimal increases for nonkindergarten services and a funding decrease for kindergartensall in the name of equity. Treasury also said any extra money needed could come from a decrease in university expenditure (Meade 1990).

Education was increasingly treated as a marketplace in which to invest, and early childhood education and care emerged in the eyes of policymakers in New Zealand and worldwide as a promising economic resource (OECD 2006). It would prepare the learner for the knowledge economy, release family members to serve the labour market and provide a competitive and rapidly growing educational market for ECE services. Without a history of public education and with very few collective safeguards in place, ECE was easily picked off for early marketisation and commercialisation-directions that accorded well with the neoliberal government. In its new devolutionary mode, the government 
reconceptualised the market as a modern form of democracy. ECE became a service to be delivered as part of an enterprise culture, organised according to market principles with concurrent elements of competition, profit-making and entrepreneurialism.

For the next decade, enterprise culture prevailed in ECE, with attendant budget cuts and growth in market-provided services. In 1990, the government released its Economic and Social Initiative (Bolger et al. 1990), a neoliberal economic and social agenda that wreaked havoc on social and health policy, including education. This agenda appropriated ideas of fairness, self-reliance, efficiency and personal choice (Wells 2015) in neoconservative ways as social welfare benefits were cut and new laws effectively undermined working conditions. The Employment Contracts Act 1991 favoured employers and weakened the collective bargaining powers of unions. Within the ECE sector, a range of measures impeded sectoral development, including deregistration of kindergarten teachers and their removal from the State Sector Act, the introduction of bulkfunding childcare centres and a new regime of contestable funding for advisory support services. These initiatives painted a gloomy picture for early childhood teachers and the social sector overall:

Kindergarten teachers are the lowest paid teachers in the state sector. Childcare workers' pay rates vary, but may be as low as the minimum wage. And the rights of the workers to fair employment arrangements have been eroded since the passing of the Employment Contracts Act. (Mitchell 1995: 78)

There was a widespread and growing malaise about the failure of the neoliberal reforms. Social and economic prosperity was promised through the sale of state assets, the corporatisation of welfare services and an ethos of competitive individualism and consumer choice. The failure of the project was well documented at the time, particularly in education (see, for example, Haworth 1994; Kelsey 1995; Wilkinson 1995; Peters and Marshall 1996; Marginson 1997; Jesson 1999; Peters and Roberts 1999). Also well documented are the social and economic consequences of a decade of market-based reforms characterised by a shift in economic benefits from the public to the private sphere and an associated deterioration in social and economic conditions, particularly for historically marginalised communities (Kelsey 2002). 
Linda Mitchell (2015) sees policy agendas during this time reflecting two distinctly different views of the role of the state in ECE: a supportive state and a minimal state. These views mark out, respectively, a Labourled collaborative approach of support and community and a National-led 'responsibilising' of families to meet social obligations, although neither of these approaches is pure. What emerged around the turn of the century is what became known in some Western economies as 'the third way' (Blair 1998) — a centrist political path that tries to reconcile right-wing neoliberal politics and left-wing social-democratic politics by advocating a varying synthesis of centre-right economics and centre-left social policies. As in the New Zealand experiment during the 1980s (Kelsey 2002), this middle ground involved a minimisation of the role of government and a rise in managerialism and performance cultures across all traditionally public service sectors (Giddens 2002).

The third way was not without its critics, having been depicted as a 'political project whose objective is short-term political management, not transformation ... a more deeply embedded form of neoliberalism that perpetuates the tensions which the Government was elected to relieve' (Kelsey 2002: 50). Nevertheless, New Zealand followed suit, with the then social development and employment minister Steve Maharey preferring to call this approach 'the new social democracy'. He saw it as a bringing together of values and politics, with some common themes emerging from consideration of economic management in relation to the role of the welfare state. The new social democracy, he claimed, was about:

An active role for the state in a mixed economy. A new alignment between economic and social policy. Partnership, citizen engagement, and democratic governance. A refurbishing of the institutions of the state and the institutions of civil society ... [and] much more besides. (Maharey 2001)

Third-way values promoted an inclusive approach to politics, so the social and political climate was right for the emergence of Pathways. In 2002, the new Labour-led Government espoused values such as equality, community and social justice, with the education minister Trevor Mallard emphasising a commitment to ECE funding - specifically, more support for community-based provision and funding for the development of an early childhood strategic plan. The minister worked closely with Linda Mitchell, in particular-a collaboration regarded as critical to the development of the plan and its grounding in a language of rights 
and participation (May 2017). From 1999, there was a stronger policy emphasis on ECE. An early childhood education strategic plan working group was set up in 2000, led by Anne Meade, who had developed Education to Be More a decade earlier. The group engaged in nationwide consultation, reflecting Aotearoa New Zealand's 'long tradition of community involvement and provision' (Meade and Podmore 2002: 29), and maintained a focus on key issues identified decades earlier in Before Five - funding, quality, access and participation—albeit with quite different purposes.

Pathways to the Future: Ngā Huarahi Arataki (MoE 2002) was Aotearoa's first 10-year strategic plan for the sector. As with Education to be More, quality, access and funding remained pivotal and critical issues were identified around adult-child ratios, teacher qualifications, sectoral regulation and teacher registration. However, some of the policy drivers had changed. ECE was now integral to the nation's economic and social planning. Pathways reflected the government's view of how ECE would contribute to the future economic health of the nation, arguing that the early years were critical to a child's later academic and vocational success. The plan focused on fostering stronger links with family, community, social services, health services and schools, as part of a seamless educational paradigm. It set out goals for increasing participation rates, particularly for Māori and Pasifika children. Unlike pre-1980s, there was widespread support for ECE outside the home to support parental employment.

\section{Political decision-making process: Motivations and contextual factors}

The design process of Pathways is interesting, due to the sector's political history, its engaged advocacy over a sustained period and its variable connectedness as a sector. Capitalising on the government's turn towards a socially progressive direction, Pathways drew on the sector's collective history and advocacy, artfully addressing political and social concerns. It effectively supported the diversity of the sector, rather than approaching issues of quality and participation through increased regulation or technocratic policy design. Other factors impacting on design were the cohesiveness of curriculum and assessment developments, the emerging international narrative of children's rights and growing support for systematic provision of education. 
The 1990s was a difficult period for the realisation of quality goals in $\mathrm{ECE}$, in terms of funding, qualifications and research. Nevertheless, the sector was strongly positioned by the development of the curriculum, Te Whäriki-a national curriculum for ECE. As sectoral advocates and internationally recognised academics, Helen May and Margaret Carr were well positioned and successful in their bid to develop this curriculum and led a highly consultative and collaborative process of curriculum design and development for more than four years. Working alongside Tilly and Tamati Reedy and Rose Pere (leaders in Māori education and Kōhanga Reo), ${ }^{2}$ they developed both a bicultural and a Māori immersion curriculum for ECE. The draft document of Te Whäriki was released for consultation in 1993, followed by the final version in 1996, which received international accolades. Curriculum is a highly contestable area of engagement, requiring political savvy, technical knowhow and a socially nuanced response to competing demands. May and Carr, between them, had a history of political advocacy and the right leadership experience to gain the acceptance and trust of a very diverse sector in driving through the radical changes. As leaders, they had an intimate knowledge of the sector at all levels and had been politically active for decades in mapping the landscape.

Unions also influenced the design process. In 1996, Future Directions: Early childhood education in New Zealand (NZEI 1996), a report from a group of community-based ECE organisations, provided a blueprint for the future of the sector. The report argued for equity funding (including pay equity with primary schoolteachers), sessional funding, accessibility for all children, accountability tied to quality, an increase in funding for discretional grants, initiatives to encourage Māori and Pasifika into ECE teaching, the Diploma of Teaching ECE to be set as a benchmark for the person responsible in a childcare centre and funding for the development of an early childhood strategic plan. Wells argues:

While never attributed to the report or as a result of the sector and public pressure during the campaign, a number of policy changes were subsequently made ... increases to funding, and the introduction of a framework and tools to improve quality - the 'Quality Journey', a new category of 'quality' funding, the development of equity criteria, and funding for pathway programmes to upgrade qualifications. (Wells 2015: 6)

2 Te Kōhanga Reo National Trust for Māori language immersion early childhood education. 
Although the focus to that point had been on a national early childhood context, what arose during this period was an increasingly active global political agenda supporting the development of ECE in Aotearoa. The United Nations and the OECD strongly influenced policy and curriculum direction. The United Nation's Convention on the Rights of the Child (UN 1989) impacted on curriculum and social policy development and was influential in bringing attention to equity issues for childrenspecifically, children's poverty and their lack of a voice in determining their own futures. The OECD's emphasis was different-focused more on strengthening global economies through economic and social wellbeing. Its reports on the significance of human and social capital in a nation's economic advancement argued that ECE had a significant, instrumental role in supporting labour markets, promoting social cohesion and furthering the economic success of a country (OECD 2001, 2006). Early childhood education and care, it argued, were important to the economic and social realms of member countries, so member countries should maintain strong ECE systems that integrated both policy and curriculum. The OECD's Starting Strong series of publications has provided education policymakers with data on member nations' ECE sectors and analysis of ECE policy-the purpose being to provide ongoing policy guidance in such a way as to leave no doubt about the critical role of government in attending to the contribution of ECE to a nation's wellbeing and economic competitiveness.

It is within this context—of national curriculum and policy emerging in response to international economic reports - that the new Labourled Government came to power in 1999 and the effects of a seemingly kinder, gentler third-way approach began to be felt. Kindergarten teachers who had been removed from the State Sector Act were reinstated and the 2000 Budget boded well for ECE development. In an address to the New Zealand Educational Institute (NZEI) conference, Mallard (2000) emphasised the government's commitment to ECE, outlining as key areas of development increasing participation, quality and qualification, and a new strategic plan to develop a coherent strategy for ECE, building on Before Five. The strategy was to address issues of support for Māori and Pasifika children; it also promised to increase participation, reduce costs to parents, address teacher supply shortages, increase support for professional development, expand grants to support the provision of new services and introduce structural support for a qualified workforce (Farquhar 2000). 
Before its election in 1999, the Labour Party pledged to convene a working group to develop a strategic plan for ECE policy (Meade and Podmore 2002). This was the first strategic plan for early childhood or for any education sector in New Zealand. The working group members represented key stakeholder organisations and, despite not always agreeing, they 'managed through democratic processes and some common values to shape a final report' (Mitchell 2011: 219).

The working group argued that ad hoc changes in policy over the previous 10 years had caused a number of significant difficulties and put forward 20 strategies for Cabinet consideration. Their report to the Minister of Education (in October 2001) set out four directions. They argued for increased access, participation and engagement, strengthening collaborative relationships and improving quality and sustainability. Three major themes characterised the proposals: enhancing policies and settings to facilitate the full implementation of Te Whäriki, better coordination of services and transformation of the role of government so ECE would be provided in partnership with government.

The final version of Pathways was developed over 15 months, with a working group of 31 members, chaired by Anne Meade. It involved open consultation with the wider ECE sector, including several hui (meetings) with Māori and fono (meetings) with Pasifika peoples, attracting more than 1,300 submissions. It set out ways for increasing participation, quality and collaboration through review of regulations and funding systems, through investment in ongoing research to inform future policy and monitor progress and through involving the sector in ongoing policy development and implementation. Pathways clearly signalled a change from 'business as usual'; regulations and funding were to be revised, but the biggest shift in direction was the call for

better support of community-based ECE services, including licenceexempt groups ... professional registration requirements for all teachers in teacher-led ECE services ... better co-operation and collaboration between ECE services, parent support and development programmes and education, health and social services ... [and] greater involvement by the Government in ECE, focussing particularly on communities where participation in quality ECE is low. (MoE 2002: 2)

As a comprehensive, stepped plan, Pathways is arguably the most important piece of ECE policy in recent times. It articulated the political and social vision for later policy initiatives. It laid out targets and monitoring 
mechanisms for the next 10 years and it successfully synthesised previous decades of advocacy and piecemeal policy responses into one coherent and widely accepted plan. It provided clearer and more visible goals for the Ministry of Education and provided greater impetus and support for the implementation of Te Whäriki. It focused on the development of a strong, community-based sector, supported through government provision, particularly in areas of need-specifically, Māori and Pasifika children and families. It was comprehensive in its prescription for developing the sector: equity grants for establishing childcare centres in areas not well served by ECE, discretionary grants to support teacher qualifications to reach a 100 per cent qualified workforce by 2012, professional learning provisions for teachers and a sector that was informed by research. This last initiative was realised through the highly acclaimed teacher-research partnership Centres of Innovation, reflecting the policy focus on support and information. The published version of the strategic plan did not include all the working group's recommendations, although it was considered aspirational for the government and the sector:

[T] he government had shifted from a minimal role, providing only low-regulated staffing standards, limited funding and a competitive market framework in teacher education and advisory support services during the early 1990s to a much more supportive role in these aspects especially during the years 2000 to 2009 (the three terms of a Labour-led government). (Mitchell 2011: 219)

The influence of the OECD on ECE was felt both nationally and internationally through reports steeped in human capital theory, such as Babies and Bosses (OECD 2002) and the beginning of a series of reports entitled Starting Strong (OECD 2001, 2006). The OECD's influence continued with their later report Starting Strong III (OECD 2012), dedicated to policy design through the development of a policy toolbox-a metaphor identifying key policy 'levers': goals and regulations; curriculum and standards; qualifications, training and working conditions; engaging families and communities; and data, research and monitoring. Each of these levers can be seen as having a role to play in the design of the strategic plan, giving Pathways a perceived seal of international approval.

In terms of its third-way policy aims, the design process for Pathways can be seen as an attempt to balance tensions inherent in the role of government regulating a very new education market. While the working group developed a comprehensive plan for government management of ECE to further social and community goals, private sector lobby 
groups such as the Early Childhood Council (formed in 1991) favoured decentralisation and marketisation of services. For them, the effectiveness of Pathways would be measured in terms of reduced policy intervention and increased participation.

\section{Implementation, legitimacy and enduring change}

Specific actions to support implementation of the strategic plan were decided in 2002 and developed in subsequent years. The collaborative, sector-driven approach of Pathways was supported by the Ministry of Education, which engaged in intensive consultation with the ECE sector on all regulatory proposals regarding standards. Ministry consultation extended from 2003 up to the implementation of the new regulatory framework in late 2008. In this way, the country achieved strong acceptance of proposals for regulatory change and workable mechanisms for implementation. The framework provided a clear and transparent statement of regulated requirements. It set out the legislative and regulatory criteria to be used in assessing compliance and standards (OECD 2012). During this period, a new funding system was established incentivising teacher-led services to employ registered teachers: 'ECE was given new financial priority during the implementation of the strategic plan and government expenditure on ECE increased almost fourfold' (Mitchell 2011: 291).

Significant progress was made towards achieving the 100 per cent qualified teacher target and improving teachers' professional learning and support. Improvements included teacher professional development, publication of assessment for learning exemplars Kei Tua o Te Pae (MoE 2005, 2007, 2009a), self-review guidelines for teachers (MoE 2006) and the establishment of the Centres of Innovation-a government-funded research initiative that linked childcare centres with research associates to research their own innovative practices. Progress was made on salary equity between kindergarten teachers and schoolteachers. Additional funding in the form of ' 20 Hours Free ECE' (later renamed '20 Hours ECE') reflected the plan's focus on increasing participation by making ECE more affordable. 
A further critical element in the success of Pathways was the way it set out a framework in which curriculum and assessment developments within the sector were implicit. Curriculum and assessment became the objects of intense scholarship and the development of new ECE curriculum and assessment discourses contributed to the formation of the sector's character and contribution. At this time, gains were being made in the ECE research community, with growing teams of academics working in the new faculties of education (formed by mergers of teacher education institutions with universities) - raising awareness of the significant role Aotearoa New Zealand was playing in ECE. The plan for a qualified sector had generated significant growth in the provision of ECE teacher education and in undergraduate student numbers, providing growth for the tertiary sector. This resulted in more academic pathways for ECE teachers to work in tertiary education. Hence, the period 2002-08 was recognisably fertile in terms of the development of ECE, including an openness to critical debate about issues impacting the sector. It was acceptable to question the drivers of the sector and how early childhood care and education centre communities understood and provided quality education and care. Watchdog organisations such as the Child Forum emerged with a focus on issues of quality.

Concerns about the growth and direction of the sector were amplified when a new centre-right government was formed in 2008, which held power for three terms (nine years). A number of economic and political factors effectively curbed the improvements that Pathways might otherwise have provided for the sector, effectively cutting short comprehensive, systemic reform. Compounding the effect of a more conservative government, a global economic downturn halted and reversed the aims of Pathways. According to Mitchell (2015), within weeks of the new conservative government being elected, Pathways was removed from the Ministry of Education's website, foreshadowing changes that were to come. The first half of 2009 saw a raft of funding halts, including severe cuts to teachers' professional development, axing of Centres of Innovation research, dropping the 100 per cent qualified teacher target, eliminating the top funding bands for qualified staff and removing the word 'free' from ' 20 Hours Free ECE'. Effectively, there was a strong move towards market-based ECE, an equalisation of funding for community-based and market-based provision and a shift from universal to targeted provision (Mitchell 2015). 
Although another strategic plan did not emerge until 2018, there was a range of policy and curriculum actions in the interim, including a taskforce to review ECE policy and a working group to review the implementation of Te Whäriki. In 2010, the ECE Taskforce, led by Michael Mintrom, was established to review and reform ECE policy and to propose a new funding model that did not increase expenditure. The taskforce was operating within limited terms of reference, which were to focus on efficiency, effectiveness and cost-saving. Its report the following year, An Agenda for Amazing Children, stressed that the taskforce was 'concerned to show that universal access to high quality ECE for every young person is our best bet for placing New Zealand on an upward trajectory in terms of both social and economic outcomes' (MoE 2011:4). Among its recommendations was a review of the implementation of the curriculum, amid unease about the quality of care and education for infants and toddlers and home-based services. May (2015) argues that this report was a repositioning of the strategic plan away from government support for universal provision and a reprioritising of spending towards 'priority children'. The report received mixed reviews:

While a number of aspects of the report were well received, others were of concern. The report stopped short of recommending a return to [the] $100 \%$ qualified teacher target ... parents pay more for ECE ... Some traction [was] gained, but by and large the recommendations remain just that. (Wells 2015: 10)

It is useful to view this period of policy development in light of the government's social policy direction. The Better Public Services Advisory Group was established to provide advice on state sector reform, with the goal to produce 'a public service and state sector that is achieving valuefor-money, is innovative, provides high-quality services and manages change effectively' (New Zealand Government 2011: 3). The group identified two critical areas for improvement: 'services for children aged 0-6 from families with multiple issues' (New Zealand Government 2011: 29) and 'educational outcomes for a sizeable cohort of young Māori and Pasifika' (p. 31). The advice focused on increasing accountability and communication across services, citing the global economic downturn as the reason for needing to contain costs and realign services. In full business-speak, it suggested gearing up state services to enable system-wide change to produce 'measurable results' and 'action plans' (New Zealand Government 2011: 10) that enhance 'flexibility', suggesting that agencies 'drive continuous business process improvement through the use of "lean" 
methodologies, and drive innovation by benchmarking activity, identifying and implementing best practice from across the system' (p. 11). Public services were to have stronger coordination to capitalise on economies of scale and 'more interaction with citizens, including via new technologies' (New Zealand Government 2011: 20). The reforms were to achieve 'better results', 'better services', 'value-for-money', 'stronger leadership' and 'the right culture and capability' (New Zealand Government 2011: 22).

This climate of business-style efficiency and improvement underpinned the models for targeting priority areas for the next six years. In 2010, the ECE Participation Programme was launched, targeting areas of society with low ECE participation rates—namely, Māori, Pasifika and low socioeconomic communities. Initiatives were set up to encourage participation, including discretionary funding to providers to establish services, family caseworkers in schools and supported playgroups. It is within this context that the 2011 discussion paper on vulnerable children was launched, with a highly controversial amendment to the Social Security Act. One of the key reforms was that any social security beneficiary with a preschool-aged child was required to enrol their child in ECE, under the sanction of benefit cuts for noncompliance. The new direction caused strong commentary and concern about the stigmatising of children as vulnerable and the coercive nature of the new government requirement. May (2015) suggests the debate about universal and targeted approaches to funding is illustrative of deeper, conflicting political agendas. On the one hand, ECE is seen as part of an interventionist strategy to 'redress the "risks" created by "vulnerable families and communities"; on the other, ECE is viewed 'as a right for the young child citizen' (May 2015: 166). This tension between universal rights and targeted interventions has been a major challenge for ECE policy in New Zealand since the mid1980s. Pathways has successfully catered to both interventionists and rights advocates by taking a flexible approach that ensured the plan would endure.

\section{Analysis and conclusion}

Although Pathways may not have achieved all of its original intentions, it has provided scope for political resistance, the testing of agendas and consistent advocacy for stronger government support for the sector. It constitutes a coherent platform for systematic development of national 
curriculum initiatives that attenuate the worst impacts of global economic imperatives. Addressing the Early Childhood Convention in 2015, chief executive of New Zealand Kindergartens Clare Wells (2015: 13) observed that, over the past decade or so, it feels like New Zealand has taken two steps forward and one step back, although, she claims, 'we are still moving forward':

We are seen as a world-leader in early childhood education for our diversity, our integrated approach, and our curriculum Te Whäriki. Our belief that every child has a right to high quality early childhood education is unequivocal. The past few decades have seen remarkable change in the world of early childhood education in Aotearoa New Zealand: the early childhood education landscape has shifted in response to drivers and influencers of change-in whose interests? (Wells 2015: 1)

The positioning of New Zealand as a world leader is debatable, given the OECD's data and rankings on early childhood policies, practices and conditions and, in particular, New Zealand's lowest ranking for teacher pay (OECD 2012). Nevertheless, the development of policies, including Pathways, is world leading. Pathways can be considered a success for the way it—along with associated policies since Before Five — contributed to a comprehensive (albeit hotly debated) early childhood agenda and to the very idea of becoming world-leading. However, New Zealand still has a long way to go in dealing with educational and health inequities for children.

From 2002 to 2008, Pathways provided a blueprint for strong early childhood policy at the same time as allowing for ongoing dialogue and debate. During this time, the sector experienced significant growth, which translated into associated growth in higher education and in research and scholarship. The strength in research and scholarship provided further support for enduring leadership and advocacy for children and for ECE. This strength will, no doubt, be called on again, as the coalition government elected in 2017 has recently announced the development of a new strategic plan. As before, the success of the new strategic plan will be assessed in terms of its capacity to increase national awareness of the complexity of the sector through ongoing political debate. It will also be important to reconcile (or at least balance) competing politics and philosophies. And it will be vital to realise quality care and education for children, families and communities. 


\section{References}

Blair, T. 1998. The Third Way: New politics for the new century. London: The Fabian Society.

Bolger, J., Richardson, R. and Birch, W. 1990. Economic and Social Initiative: December 1990. Statements to the House of Representatives. Wellington: Government Printer.

Department of Education 1988. Before Five: Early childhood care and education in New Zealand. Wellington: Government Printer.

Farquhar, S. 2000. A narrative analysis of policies and reforms in early childhood education (Aotearoa/New Zealand). Unpublished Masters thesis, University of Auckland, Auckland.

Farquhar, S. and Gibbons, A. 2010. 'Early childhood education.' In M. Thrupp and R. Irwin (eds), Another Decade of New Zealand Education Policy: Where to now? Hamilton, NZ: Wilf Malcolm Institute of Educational Research, University of Waikato.

Gibbons, A. and Farquhar, S. 2014. 'Mapping policies and pathways in early childhood education: A note from Aotearoa New Zealand.' New Zealand Research in Early Childhood Education Journal 17(1): 1-10.

Giddens, A. 2002. Where Now for New Labour? Cambridge: Polity Press.

Haworth, N. 1994. Neo-liberalism, Economic Internationalism and the Contemporary State in New Zealand. Auckland: Auckland University Press.

Jesson, B. 1999. Only their Purpose is Mad. Palmerston North, NZ: Dunmore Press.

Kelsey, J. 1995. The New Zealand Experiment: A world model for structural adjustment? Auckland: Auckland University Press.

Kelsey, J. 2002. At the Crossroads. Wellington: Bridget Williams Books.

Maharey, S. 2001. Values and politics: Some reflections on the new social democracy in a New Zealand context. Comments to a seminar hosted by the Foundation for Policy Initiatives, Auckland, 26 March. Available from: www. beehive.govt.nz/speech/values-and-politics-some-reflections-new-socialdemocracy-new-zealand-context.

Mallard, T. 2000. 'Speech notes.' In New Zealand Educational Institute, Policy, Practice and Politics: NZEI Te Riu Roa Early Childhood Millennium Conference Proceedings. Wellington: NZEI Te Riu Roa. 
Marginson, S. 1997. 'Is economics sufficient for the government of education?' New Zealand Journal of Educational Studies 32(1): 3-12.

May, H. 1990. 'Growth and change in the early childhood services.' In S. Middleton, J. Codd and A. Jones (eds), New Zealand Education Policy Today. Wellington: Allen \& Unwin.

May, H. 2015. 'New Zealand: A narrative of shifting policy directions for early childhood education and care.' In K. Stewart (ed.), An Equal Start? Providing early childhood quality and care for disadvantaged children. Bristol: Policy Press.

May, H. 2017. 'Documenting early childhood policy in Aotearoa New Zealand: Political and personal stories.' In L. Miller, C. Cameron, C. Dalli and N. Barbour (eds), Sage Handbook of Early Childhood Policy. London: Sage.

Meade, A. 1988. Education to be More: Report of the Early Childhood Care and Education Working Group. Wellington: Government Printer.

Meade, A. 1990. 'Women and young children gain a foot in the door.' Women's Studies Journal 6(1): 96-110.

Meade. A. and Podmore, V. 2002. Early Childhood Education Policy Co-ordination under the Auspices of the Department/Ministry of Education: A case study of New Zealand. Paris: UNESCO.

Ministry of Education (MoE) 1996. Te Whāriki: He Whāriki Mātauranga mō ngà Mokopuna o Aotearoa-Early childhood curriculum. Wellington: Ministry of Education.

Ministry of Education (MoE) 2002. Pathways to the future: Ngā huarahi arataki-A ten year plan for early childhood education. Wellington: Ministry of Education.

Ministry of Education (MoE) 2004. Professional Standards for Kindergarten Teachers and How to Integrate These into Kindergarten Performance Management Systems: A practical resource for kindergarten associations, kindergarten teachers, head teachers and senior teachers. Wellington: Ministry of Education.

Ministry of Education (MoE) 2005. Kei Tua o te Pae: Assessment for learningEarly childhood exemplars. Books 1-10. Wellington: Learning Media.

Ministry of Education (MoE) 2006. Ngā Arohaehae Whai Hua: Self-review guidelines for early childhood education. Wellington: Learning Media.

Ministry of Education (MoE) 2007. Kei Tua o te Pae: Assessment for learningEarly childhood exemplars. Books 11-15. Wellington: Learning Media. 
Ministry of Education (MoE) 2009a. Kei Tua o te Pae: Assessment for learningEarly childhood exemplars. Books 16-20. Wellington: Learning Media.

Ministry of Education (MoE) 2009b. Te Whatu Pōkeka: Kaupapa Māori assessment for learning -Early childhood exemplars. Wellington: Ministry of Education.

Ministry of Education (MoE) 2011. An Agenda for Amazing Children: Final report of the ECE Taskforce. Wellington: Ministry of Education.

Mintrom, M. and Norman, P. 2009. 'Policy entrepreneurship and policy change.' The Policy Studies Journal 37(4): 649-67. doi.org/10.1111/j.15410072.2009.00329.x.

Mitchell, L. 1994. 'Current policy issues for women: What has happened to early childhood education.' Women's Studies Journal 10(2).

Mitchell, L. 1995. 'Crossroads: Early childhood education in the mid-1990s.' New Zealand Annual Review of Education 5: 75-92.

Mitchell, L. 2011. 'Enquiring teachers and democratic politics: Transformations in New Zealand's early childhood education landscape.' Early Years 31(3): 217-28. doi.org/10.1080/09575146.2011.588787.

Mitchell, L. 2015. 'Shifting directions in ECEC policy in New Zealand: From a child rights to an interventionist approach.' International Journal of Early Years Education 23(3): 288-302. doi.org/10.1080/09669760.2015.1074557.

New Zealand Educational Institute (NZEI) 1996. Future Directions: Early childhood education in New Zealand. Wellington: NZEI Te Rui Roa.

New Zealand Government 2011. Better Public Services Advisory Group Report. Wellington: New Zealand Government.

Organisation for Economic Co-operation and Development (OECD) (n.d.). International Early Learning and Child Well-being Study. Paris: OECD Publishing. Available from: www.oecd.org/edu/school/international-earlylearning-and-child-well-being-study.htm.

Organisation for Economic Co-operation and Development (OECD) 2001. Starting Strong: Early childhood education and care. Paris: OECD Publishing.

Organisation for Economic Co-operation and Development (OECD) 2002. Babies and Bosses. Paris: OECD Publishing.

Organisation for Economic Co-operation and Development (OECD) 2006. Starting Strong II: Early childhood education and care. Paris: OECD Publishing. 
Organisation for Economic Co-operation and Development (OECD) 2012. Starting Strong III: A quality toolbox for early childhood education and care. Paris: OECD Publishing.

Peters, M. and Marshall, J. 1996. Individualism and Community: Education and social policy in the postmodern condition. London: The Falmer Press.

Peters, M. and Roberts, P. 1999. University Futures and the Politics of Reform in New Zealand. Palmerston North, NZ: Dunmore Press.

Ritchie, J. and Ritchie, J. 1970. Child Rearing Patterns in New Zealand. Wellington: A. H. \& A. W. Reed.

State Services Commission 1980. Report on Early Childhood Care and Education. Wellington: State Services Commission.

United Nations (UN) 1989. Convention on the Rights of the Child. New York: United Nations.

Wells, C. 2015. In whose interests: Looking back-Thinking forward. Keynote address to Early Childhood Convention: He Wai Whakariporipo-Making Waves in Early Childhood-Surviving the Storm, Rotorua, New Zealand, 4 October.

Wilkinson, M. 1995. 'Rationality, efficiency and the market.' In J. Boston (ed.), The State Under Contract. Wellington: Bridget Williams Books. 
This text is taken from Successful Public Policy: Lessons from Australia and New Zealand, edited by Joannah Luetjens, Michael Mintrom and Paul 't Hart, published 2019 by ANU Press, The Australian National University, Canberra, Australia.

doi.org/10.22459/SPP.2019.19 